\title{
Kompetensi Komunikasi Tutor Dalam Meningkatkan Kepercayaan Diri Peserta Didik
}

\author{
Dina Novika \\ Universitas Muhammadiyah Sumatera Utara \\ e-mail: dinanovika@gmail.co.id
}

\begin{abstract}
Communication play an important role in all aspects of life, because it gives the the contribution of large in the process of attention was given to disseminating a message in the form of information and knowledge especially in helping them to education. How is it possible provide us with information communication with nothing to do, fuel price hike worried investors the communication in the world education is teachers as the communicators the and participants primary school students as communicant. A tutor which has fixed and firm the competence of a communication that good will to be able to draw sympathy school tuition than right now to heed, understand, and for the remembrance of a message on the great commission nor information to in this matter is the subject matter. Aim of this study is under way to find out the competence of communication a tutor in improving the a belief in themselves school tuition at the Yayasan Pemimpin Anak Bangsa. A theory that used in this research is a theory constructivism, the theory is well explain how ability or very works of their hands sunday prologue an individual in communications. The study used a qualitative approach was adopted with the methods observation, the objective of the interview, and documentation. The results of the research showed it was personal communication tutor at the Yayasan Pemimpin Anak Bangsa has been good enough, was seen from ability tutor use verbal communication and nonverbal messages and subject matter that is easily understood by students, a tutor who are providing support, motivation and spirit to learn back.
\end{abstract}

Key Word: Competence communication, competence tutor, confidence

\begin{abstract}
Abstrak
Komunikasi berperan penting dalam segala aspek kehidupan, karena memberikan sumbangsih besar dalam proses penyampaian pesan berupa informasi dan pengetahuan khususnya dalam pendidikan. Bagaimana mungkin memberikan informasi tanpa melakukan komunikasi, Pelaku komunikasi dalam dunia pendidikan adalah guru sebagai komunikator dan peserta didik sebagai komunikan. Tutor yang mempunyai kompetensi komunikasi yang baik akan dapat menarik simpati peserta didik untuk mendengarkan, memahami, dan mengingat pesan ataupun informasi dalam hal ini adalah materi pelajaran. Kajian ini bertujuan untuk mengetahui kompetensi komunikasi tutor dalam meningkatkan kepercayaan diri peserta didik di Yayasan Pemimpin Anak Bangsa. Teori yang digunakan dalam penelitian ini adalah teori konstruktivisme, teori ini menjelaskan bagaimana kemampuan atau kecakapan individual dalam berkomunikasi. Kajian ini menggunakan pendekatan kualitatif dengan metode observasi, wawancara,
\end{abstract}


dan dokumentasi. Hasil dari kajian ini menunjukkan kompetensi komunikasi tutor Yayasan Pemimpin Anak Bangsa sudah cukup baik, itu dilihat dari kemampuan tutor menggunakan komunikasi verbal dan nonverbal dengan baik sehingga pesan-pesan materi pelajaran yang mudah dipahami oleh peserta didik, tutor yang selalu memberi dukungan, motivasi dan semangat untuk belajar kembali.

Kata Kunci : Kompetensi komunikasi, kompetensi tutor, kepercayaan diri

\section{Latar Belakang Masalah}

Sudah 72 tahun Indonesia dikatakan merdeka secara de facto dan de jure. Tentunya di usia yang matang ini Indonesia harusnya sudah unggul dalam segala aspek terkhusus pendidikan. Salah satu cita-cita kemerdekaan Indonesia yang juga terdapat dalam Pembukaan UUD 1945 adalah mencerdaskan kehidupan bangsa. Namun sayangnya, salah satu cita-cita luhur kemerdekaan ini seolah masih jauh dari kata ideal. Masih banyak anak bangsa yang belum dapat merasakan pendidikan dengan layak. Data Kemendikbud menunjukkan, pada 2015/2016 ada 946.013 orang siswa yang lulus SD tidak melanjutkan ke SMP. Dan ada 68.066 anak lainnya yang putus di SD. Sementara data UNICEF tahun 2016 menyebutkan ada 2,5 juta anak Indonesia yang tidak bisa menikmati pendidikan lanjutan, yakni 600 ribu anak usia Sekolah Dasar (SD) dan 1,9 juta anak usia Sekolah Menengah Pertama (SMP). Dan hanya 44 persen anak Indonesia yang berhasil menuntaskan pendidikan menengah.Sumber Berdikari Online (http://.berdikarionline.com/read/201 7/08/20/72-Tahun-Merdeka-dan-

Cita-Cita-Mencerdaskan-Bangsa). Menurut UU No.2 Tahun 1989 dan PP No. 73 Tahun 1991, pendidikan diselenggarakan melalui dua jalur, yaitu jalur sekolah dan jalur luar sekolah. Pendidikan Nonformal adalah pendidikan yang diselenggarakan di luar jalur atau sistem pendidikan sekolah, baik lembaga maupun tidak dilembagakan, yang tidak harus berjenjang dan berkesinambungan. Salah satu program pendidikan nonformal adalah pendidikan berkelanjutan yang salah satunya adalah program pendidikan kesetaraan. Pendidikan Kesetaraan merupakan pendidikan nonformal yang mencakup program Paket A 
setara SD/MI, Paket B setara SMP/MTs, dan Paket C setara SMA/MA dengan penekanan pada penguasaan pengetahuan, keterampilan fungsional serta pengembangan sikap dan kepribadian profesional peserta didik. Hasil pendidikan nonformal dapat dihargai setara dengan hasil program pendidikan formal setelah melalui proses penilaian penyetaraan oleh lembaga yang ditunjuk oleh Pemerintah atau pemerintah daerah dengan mengacu pada Standar Nasional Pendidikan (UU No 20 Tahun 2003 Pasal 26 Ayat 6 Tentang Sistem Pendidikan Nasional).

Tutor adalah sebutan bagi pendidik pada pendidikan nonformal. Dalam membimbing peserta didik untuk aktif mempelajari materi maka tutor wajib menggunakan komunikasi yang baik. Kemampuan berkomunikasi memang merupakan suatu hal yang sangat fundamental bagi seorang pendidik. Bagaimana mungkin memberikan informasi dalam mengajar tanpa melakukan komunikasi. Harold D. Laswell (Nurudin, 2010) menjelaskan bahwa komunikasi pada dasarnya merupakan suatu proses yang menjelaskan siapa? (sumber), mengatakan apa? (pesan), dengan saluran apa? (media), kepada siapa? (penerima), dengan akibat atau hasil apa? (efek).Definisi dari Laswell merangkum dengan jelas unsur-unsur komunikasi, yaitu adanya sumber (source), pengirim pesan (communicator), media (channel), penerima pesan (communicant), dan efek (effect).

Tutor yang merupakan komunikator, materi pelajaran sebagai pesan atau informasi, peserta didik sebagai komunikan, media/alat pembelajaran, serta respon atau umpan balik (feedback). Sebagai komunikator yang dapat memberikan pesan-pesan atau pengetahuan dengan tepat, tutor seharusnya mempunyai kompetensi komunikasi yang baik. Kompetensi Komunikasi adalah kemampuan yang meliputi pengetahuan, keterampilan dan sikap yang sesuai dalam mengelola pertukaran pesan verbal dan nonverbal berdasarkan patokanpatokan tertentu dari komunikaor (tutor) kepada komunikan (peserta didik) yang mengharapkan umpan balik dan menimbulkan efek-efek tertentu. 
Tutor merupakan tenaga kependidikan yang bertugas dan bertanggung jawab memberikan bantuan belajar kepada peserta didik dalam proses pembelajaran jarak jauh dan/atau pembelajaran tatap muka pada satuan pendidikan jalur formal dan nonformal (Danim 2015). Surya (2014) mengatakan proses belajar mengajar pada hakikatnya merupakan suatu bentuk interaksi antara pihak pengajar dengan pelajar yang berlangsung dalam situasi pengajaran dan untuk mencapai tujuan pengajaran. Dalam interaksi itu akan terjadi proses komunikasi timbal balik antara pihak-pihak yang terkait yaitu antara guru dan peserta didik.

Dalam bidang pendidikan, pastinya kompetensi seorang tenaga pendidik sangat mempengaruhi jalannya proses belajar mengajar. Menurut Mulyasa (Hawi, 2014) kompetensi merupakan perpaduan dari pengetahuan, keterampilan, nilai dan sikap yang direfleksikan dalam kebiasaan berpikir dan bertindak. Kata competence adalah state of being capable, atau dapat diartikan sebagai suatu keadaan yang menunjukkan kapabilitas atau kemampuan seseorang sehingga ia dapat berfungsi dalam cara-cara yang mendesak dan penting. Misalnya kompetensi komunikator adalah sebuah kompetensi yang dimiliki oleh seorang komunikator atau kemampuan tertentu, kemampuan yang cukup dari seorang komunikator dalam menghindari perangkap atau hambatan komunikasi.

Yayasan pemimpin anak bangsa merupakan sebuah yayasan yang bergerak dalam bidang pendidikan, khususnya bagi anak putus sekolah untuk dapat melanjutkan pendidikannya melalui program pendidikan kesetaraan. Peserta didik pendidikan kesetaraan merupakan anak-anak yang putus sekolah karena keterbatasan ekonomi dan berbagai masalah kehidupan lainnya yang membuat mereka tidak mampu melanjutkan pendidikannya di pendidikan formal. Dengan latar belakang tersebut, dapat dipahami mereka pada umumnya memiliki rasa percaya diri yang lebih rendah atau tidak sama dengan mereka yang mengenyam pendidikan formal. Rasa percaya diri yang rendah inilah yang sering menghalangi mereka untuk 
maju. Lingkungan dan latar belakang yang berbeda mempengaruhi kepribadian serta pembentukan rasa percaya diri peserta didik. Rasa mider, malu, dan takut menjadi kendala bagi peserta didik dalam berinterkasi dengan baik dalam proses belajar.

Sedangkan percaya diri merupakan salah satu faktor keberhasilan seseorang. Percaya terhadap kemampuan yang dimiliki merupakan bekal yang sangat penting bagi seseorang dalam kehidupannya. Ketika seseorang percaya terhadap kemampuan yang dimilikinya maka dirinya akan merasa mampu melakukan suatu hal. Hal ini ditegaskan oleh Lauster (1997) yang mengatakan bahwa kepercayaan pada diri sendiri mempengaruhi sikap hati-hati, ketaktergantungan, ketidak serakahan, toleransi dan cita-cita.

Kepercayaan terhadap dirinya yang akan memotivasi untuk berusaha mencapai tujuannya. Menurut Fatimah kepercayaan diri adalah sikap positif seorang individu yang memampukan dirinya untuk mengembangkan penilaian positif, baik terhadap diri sendiri maupun terhadap lingkungan atau situasi yang dihadapinya. Kesuksesan dalam segala bidang akan sulit dicapai jika seseoarang tidak memiliki kepercayaan diri yang tinggi. Kepercayan diri haruslah dimiliki oleh semua orang termasuk peserta didik. Kepercayaan diri sangat dibutuhkan oleh peserta didik dalam pembelajaran sehingga dapat memotivasi peserta didik untuk meraih prestasi. Peserta didik yang memiliki kepercayaan diri yang kuat menganggap kegagalan bukan merupakan suatu yang menyedihkan, memalukan bahkan mematahkan semangat tetapi sebagai langkah menuju keberhasilan.

Tutor sebagai pendidik memiliki peranan dalam upaya meningkatkan kepercayaan diri peserta didik pada proses pembelajaran. Dalam hal ini tutor haruslah memerhatikan interaksi antarpeserta didik, antara peserta didik dengan tutor, serta antara peserta didik dengan materi pelajaran. Cara terbaik untuk berinteraksi adalah memahami impian peserta didik terhadap tutor ideal yang menurutnya mampu memberikan dorongan terbesar 
dalam mengajar. Pembelajaran disertai dengan pemberian motivasi dan penanaman rasa kepercayaan diri terhadap peserta didik akan meningkatkan prestasi belajar.

Tutor yang mempunyai kompetensi komunikasi yang baik akan dapat menarik simpati peserta didik untuk mendengarkan, memahami, dan mengingat pesan ataupun informasi dalam hal ini adalah materi pelajaran. Seorang tutor haruslah mempunyai kompetensi komunikasi dalam menyampaikan materi pelajaran mengingat adanya perbedaan cara belajar peserta didik, latar belakang yang berbeda yang mempengaruhi keseriusan dan fokus peserta didik. Untuk itu seorang tutor harus melakukan persiapan fisik, persiapan mental, dan persiapan materi demi menunjang proses pembelajaran.

\section{Metode Penelitian}

Kajian mengenai kompetensi komunikasi tutor dalam meningkatkan kepercayaan diri peserta didik dilakukan melalu pendekatan deskriptif kualitatif. Pendekatan kualitatif Menurut Kriyantono (2012) dapat berupa kata-kata, kalimat-kalimat atau narasi-narasi, baik yang diperoleh dari wawancara mendalam maupun observasi. Hal demikian senada dengan yang disampaikan Moleong (2007) yang mengatakan bahwa deskriptif kualitatif adalah sebagai prosedur penelitian yang menghasilkan data deskriptif berupa kata-kata tertulis dan lisan dari orang-orang dan perilaku yang dapat diamati.

\section{Hasil Penelitian dan Pembahasan}

Komunikasi berperan penting dalam penyampaian pesan-pesan berupa materi pelajaran kepada peserta didik, untuk itu tutor dituntut untuk mempunyai kompetensi yang baik. Cara penyampaian yang ekspresif akan menimbulkan efek yang positif kepada peserta didik untuk aktif dalam menangkap pelajaran.

Komunikasi adalah proses penyampaian pesan dari komunikator kepada komunikan yang mengharapkan umpan balik dan menghasilkan efek-efek tertentu. Pesan yang disampaikan mengandung informasi baru yang dapat mempengaruhi komunikan. 
Agar pesan itu tersampaikan dengan baik dan tepat tentunya seorang komunikator harus mempunyai kompetensi yang baik, sehingga proses penyampaian pesan tidak terjadi miss communication dan miss understanding.

Tutor merupakan fasilitator untuk peserta didiknya. Tutor yang cerdas adalah tutor yang dapat memberikan pesan-pesan atau materi pelajaran dengan baik kepada peserta didik dengan memanfaatkan media atau alat peraga yang mendukung berjalannya pembelajaran. Dalam mendukung kinerja tutor yang disebutkan, diharapkan seorang tutor memiliki kompetensi komunikasi yang baik. Kompetensi komunikasi diartikan sebagai seperangkat kemampuan seorang komunikator untuk menggunakan berbagai sumber daya yang ada di dalam proses komunikasi untuk berkomunikasi dengan baik dengan menggunakan pesan-pesan yang dianggap tepat dan efektif oleh komunikan.

Untuk menciptakan proses komunikasi yang efektif, pendidik harus memahami konsep dasar komunikasi pendidikan, antara lain mengenai proses komunikasi pendidikan, teknik berkomunikasi secara efektif, bentuk komunikasi, prinsip komunikasi, komunikasi lisan dan tertulis, dan metode yang tepat dalam komunikasi pendidikan. Dalam menjalankan kompetensi komunikasi, tutor harus memiliki kredibilitas, kemampuan intelektual, kematangan emosional, dan keterampilan komunikasi.

Seorang tutor harus memiliki kemampuan komunikasi verbal yang baik dalam menyampaikan pesanpesan atau materi pelajaran, sehingga peserta didik menjadi cerdas dan rajin belajar seperti yang diungkapkan narasumber Mawarni. Di dalam melakukan pembelajaran tutor harus dapat menguasai kelas dengan melihat perilaku dan membaca karakter peserta didik, mengendalikan suasana belajar dan dapat menjadi "teman konseling" bagi peserta didik yang mempunyai masalah. Bagi peserta didik yang memiliki semangat yang tinggi dalam belajar tentu ingin mendapatkan nilai yang bagus, sedangkan peserta didik yang kurang fokus bahkan acuh merasa tidak merasa penting baginya mendapatkan nilai yang maksimal. 
Padahal, peserta didik harus mempunyai semangat belajar dan kepercayaan diri yang tinggi untuk bekal yang dapat dibawa ke jenjang pendidikan selanjutnya.

Menurut salah seorang narasumber, keberhasilan pembelajaran tidak hanya dilihat dari bagaimana cara tutor menyampaikan pesan-pesan atau materi pembelajaran, tetapi juga dilihat dari hasil belajar. Tutor juga harus dengan jelas dalam menyampaikan materi pelajaran, selama dalam proses pembelajaran narasumber juga mengatakan bahwa suaranya sangat keras sehingga dapat didengar dengan jelas oleh seluruh peserta didik.

Demi menunjang keberhasilan dalam mengajar tutor juga harus memiliki penampilan yang rapih saat mengajar, karena penampilan merupakan awal untuk menarik peserta didik untuk belajar dan dapat memberikan semangat bagi peserta didik,

Dalam penyampaian materi seluruh tutor Yayasan Pemimpin Anak Bangsa menggunakan buku pelajaran sebagai sumber materi pembelajaran, mereka juga menggunakan soal-soal latihan yang ada di Bank Soal Ujian Nasional, berbagai sumber di internet, dan juga contoh-contoh dalam kehidupan sehari-hari sebagai gambaran. Berdasarkan hasil temuan dilapangan, tutor biasanya memberi tugas yang akan diselesaikan saat sedang pembelajaran maupun tugas rumah, saat belajar tutor juga terkadang saling bercerita dengan peserta didik dan memberikan motivasi untuk meningkatkan semangat belajar. Tutor juga tidak jarang memberi pertanyaan kepada peserta didik, dan menyuruh peserta didik maju kedepan untuk menjawab pertanyaan di papan tulis. Ini dilakukan untuk dapat menumbuhkan rasa percaya diri peserta didik agar berani menyampaikan tanggapan dan pendapatnya masing-masing.

Peserta didik di Yayasan Pemimpin Anak Bangsa menyatakan bahwa tutor sudah menggunakan seluruh kemampuan dan perhatiannya dalam memberikan materi pelajaran, walaupun beberapa peserta didik belum 100 persen mengerti dengan materi yang diberikan oleh tutor. Tutor telah 
berusaha maksimal menggunakan sumber-sumber pelajaran dari bukubuku pelajaran sebagai media dalam menunjang keberhasilan dalam belajar. Peserta didik juga menyatakan bahwa mereka mendapatkan motivasi, dukungan dan semangat belajar, karena tutor selalu memberi perhatian dan banyak menceritakan kisah-kisah orang yang pernah gagal namun bisa menjadi sukses dan banyak kisah inspiratif lainnya untuk meningkatkan semangat belajar.

Komunikasi dalam dunia pendidikan menjadi point tersendiri dalam mencapai keberhasilan tujuan pendidikan Indonesia, tutor memanfaatkan komunikasi sebagai media penyalur pesan atau materi pelajaran. Transformasi pendidikan di Indonesia berjalan dengan lamban, karena beberapa faktor seperti sumber daya manusia dan fasilitas yang masih kurang.

Kompetensi komunikasi tutor di Yayasan pemimpin Anak Bangsa Medan bisa dikatakan baik, karena tutor-tutornya menggunakan komunikasi verbal dan nonverbal dengan baik, memberikan nasihat, motivasi dan membimbing dengan sepenuh hati serta memberikan ilmuilmu yang bermanfaat sesuai dengan kapasitas peserta didik yang memiliki jenjang umur yang berbeda-beda. Para tutor mengkategorisasikan umur peserta didik saat sedang mengajar, agar terjalin komunikasi dua arah yang baik saat sedang belajar.

Tutor senantiasa memberikan senyuman terbaiknya dalam menyampaikan materi serta medengarkan setiap keluhan peserta didik yang sulit untuk memahami pelajaran dengan memberikan tanggapan yang baik kepada peserta didik. Dalam proses belajar mengajar harus tetap memegang teguh prinsip bahwasannya setiap peserta didik berhak mendapatkan pengajaran dan ilmu yang sama. Penyampaian pesan atau materi yang tegas merupakan salah satu upaya yang dilakukan untuk mempermudah peserta didik memahami materi yang didapatkan. Memberikan kesempatan bertanya dan memberikan tugas individu kepada peserta didik dilakukan dalam upaya menumbuhkan kepercayaan diri peserta didik untuk menyampaikan tanggapan dan pendapat. 
Kompetensi komunikasi tutor di Yayasan Pemimpin Anak Bangsa Medan sudah cukup baik, hal ini dapat dilihat bagaimana tutor menggunakan komunikasi verbal dan nonverbal dengan baik sehingga pesan-pesan materi pelajaran yang mudah dipahami oleh peserta didik. Upaya untuk meningkatkan kepercayaan diri peserta didik juga sudah cukup baik, yang dilakukan oleh tutor karena selalu memberi dukungan, motivasi dan semangat untuk belajar kembali walaupun mereka sudah pernah putus sekolah dan berada di usia yang tidak seharusnya dalam pendidikan formal.

Keseluruhan peserta didik di Yayasan Pemimpin Anak Bangsa Medan berasal dari latar belakang yang berbeda-beda, dan usia yang berbeda-beda. Ini menjadi fokus tutor-tutor untuk menyatukan keberagaman menjadi satu kesatuan peserta didik yang berkualitas.

\section{Penutup}

Sebagai komunikator, peran yang dilakukan oleh tutor di Yasasan Pemimpin Anak Bangsa dapat dikatakan sudah cukup baik, hal tersebut terlihat bagaimana tutor menggunakan komunikasi verbal dan nonverbal untuk menyampaikan pesan atau materi pelajaran. Tutor membimbing, menasehati dan memotivasi peserta didik untuk semangat belajar, sehingga terjadi komuniaksi dua arah yang efektif dan berdampak pada kepercayaan diri peserta didik.

Memberikan motivasi dan peningkatan pemahaman peserta didik. Serta dengan memberi pertanyaan kepada peserta didik, dan menyuruh peserta didik untuk maju kedepan menjawab pertanyaan di papan tulis. Hal tersebut dilakukan untuk dapat menumbuhkan rasa percaya diri peserta didik agar berani menyampaikan tanggapan dan pendapatnya masing-masing.

Dalam menyampaikan pesanpesan atau materi pelajaran tutor harus berpegang teguh kepada prinsip kebenaran dan kejujuran, karena komunikator menjadi jembatan bagi komunikan dalam menyampaikan materi pelajaran yang kredibel dan sesuai. Apabila materi yang disampikan kurang tepat bagi peserta didik maka tutor akan mengambil inisiatif untuk mengulang 
dan memberikan pemahaman lebih kepada peserta didik.

Proses pembelajaran yang baik apabila adanya interaksi dua arah yang memberikan umpan balik. Tidak hanya satu sisi yang memberikan informasi tetapi juga ada respon yang menanggapi kontak komunikasi yang berakhir pada tanya jawab. Apabila terjadi gangguan dalam proses pembelajaran, maka tutor akan mencari penyebab masalah tersebut.

\section{Daftar Pustaka}

Danim, Sudarwan. 2015. Profesi Kependidikan. Bandung: Alfabeta.

Fatimah, Enung. 2006. Psikologi Perkembangan: Perkembangan Peserta Didik. Bandung: CV. Pustaka Setia.
Hawi, Akmal. 2014. Kompetensi Guru Pendidikan Agama Islam. Jakarta: Rajawali Pers.

Kriyanto, Rachmat. 2012. Teknik Praktik Riset Komunikasi. Jakarta: Prenada Media.

Lauster, Peter. 1997. Tes Kepribadian. Jakarta: Bumi Aksara.

Moleong, Lexy. 2007. Metodologi Penelitian Kualitatif. Bandung: Remaja Rosdakarya.

Nurudin, 2010. Pengantar Komunikasi Massa. Jakarta: PT. Raja Grafindo Persada.

Surya, Mohammad. 2014. Psikologi Guru Konsep dan Aplikasi. Bandung: Alfabeta.

Undang-undang No. 20 Tahun 2003 Tentang Sistem Pendidikan Nasional

http://.berdikarionline.com/read/2017 /08/20/72-Tahun-Merdekadan-Cita-Cita-MencerdaskanBangsa, diakses pada 14 November 2017 